\title{
Faktor-faktor Penyebab Keterlambatan Waktu Penyediaan Rekam Medis Rawat Jalan Di RSU Madani Tahun 2019
}

\author{
${ }^{1}$ Zulham Andi Ritonga, ${ }^{2}$ Alan Juli Wannara
}

Program Studi D-III Perekam Medis dan Informasi Kesehatan, Universitas Imelda Medan

\begin{tabular}{l}
\hline \hline Article Info \\
\hline Article history: \\
Received Feb24, 2020 \\
Revised Feb 25, 2020 \\
Accepted Feb28, 2020
\end{tabular}

\section{Keywords:}

Waiting Time

Outpatient Medical Record File

\begin{abstract}
ABSTRAK
The storage system is implemented in Madani General Hospital Medan using a centralized system, which is the merging of inpatient and outpatient medical records. Outpatient and inpatient medical records are held in one location. stacked above the status that has been arranged neatly. This type of research uses descriptive through interviews and check list sheets. This research was conducted at Madani Hospital, February to June 2019. The population in this study were patients who visited the outpatient registration and overall medical records in the outpatient registration and storage section. The sample in this study was divided into two types, namely new and old outpatients and outpatient medical record personnel at Madani General Hospital. The sampling technique used was Purposive Sampling. Terminal number system can facilitate medical record personnel who are not experts in carrying out the storage work and have been implemented well. Based on location, the storage system uses centralization. The medical record file in the storage section is not neatly arranged. Where the file is stored is not enough to be lined up on the medical record filing rack, because the area of the medical record filing is insufficient so that the medical record filing rack cannot be added to the medical record storage section. There are many files piled on top of the medical record that has been arranged neatly according to the medical record number. When retrieval medical records of patients who want to seek treatment do not use tracers (exit instructions) as a substitute to be inserted in the medical record file of patients who want to seek treatment.
\end{abstract}

This is an open access article under the CC BY-SAlicense.
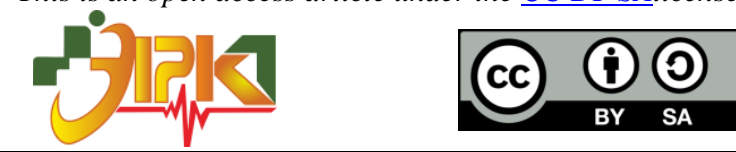

\section{Corresponding Author:}

Zulham Andi Ritonga,

Program Studi D-III Perekam Medis dan Informasi Kesehatan,

Universitas Imelda Medan,

Jl. Bilal No. 52 Kelurahan Pulo Brayan Darat I Kecamatan Medan Timur, Medan - Sumatera Utara.

Email: zulhamandi16@gmail.com

\section{PENDAHULUAN}

Rekam medis adalah satu syarat dalam meningkatkan mutu layanan RS. Salah satu unit layanan rekam medis di rumah sakit yaitu bagian penerimaan pasien rawat jalan. Tempat penerimaan pasien rawat jalan disebut loket pandaftaran berfungsi dalam layanan pada pasien dimana sebagai pemberi layanan yang pertama kali diterima oleh pasien atau keluarga pasien, sehingga baik buruknya mutu layanan rumah sakit dapat dinilai dari layanan yang diterima pasien di bagian pendaftaran. 
Tugas dan kegunaan pendaftaran rawat jalan adalah: (1) mendaftarkan pasien rawat jalan, (2) mencatat identitas pasien pada rekam medis, (3) mendistribusikan rekam medis pada masing-masing poliklinik, (4) membantu bagian keuangan dalam hal memberikan keterangan mengenai jasa pelayanan unit rawat jalan yang dibutuhkan oleh pasien serta manajemen pelanggan lainnya.

Instalasi Rawat Jalan (IRJ) adalah unit fungsional yang melayanai penerimaan pasien di rumah sakit, yaitu berobat jalan atau yang akan dirawat. Pemberian layanan di unit rawat jalan pertama dilakukan di loket karcis bagian rekam medis rawat jalan (Depkes RI, 2006).Sadapun dimensi mutu layanan kesehatan yaitu akses terhadap layanan dengan indikator waktu tunggu pasien. Waktu tunggu pasien pada layanan rekam medis pendaftaran rawat jalan adalah satu hal sangat penting yang menentukan citra atau image layanan rumah sakit. Waktu tunggu pasien adalah salah satu komponen potensial penyebab ketidakpuasan. Pasien akan menganggap layanan kesehatan buruk jika penyakitnya tidak sembuh, antrian lama dan tenaga kesehatan kurang bersahabat walupun terlatih (Pohan, 2007).

Pelayanan rekam medis yang bermutu dan baik terlihat dari keramahan, cepat dan nyaman. Pelayanan rekam medis rawat jalan diawali dari tempat pendaftaran sampai penyediaan rekam medis pasien yang akan digunakan untuk mendapatkan. Berdasarkan standar pelayanaan minimal yang ada, waktu penyediaan rekam medis rawat jalan adalah $\leq$ 10 menit (Depkes RI, 2008).

RSU Madani diresmikan pada tahun 2014 beralamat Jl. AR. Hakim No. 168 Medan dan salah satu rumah sakit umum swasta tipe $\mathrm{C}$ di kota Medan yang mendapat Akreditasi Pratama dari Komite Akreditasi Rumah Sakit (KARS) pada bulan November tahun 2016.

Berdasarkan survey awal, hasil perhitungan waktu yang dibutuhkan pada layanan rekam medis unit rawat jalan dari pendaftaran sampai dengan berkas rekam medis tersedia pada poliklinik, diperoleh bahwa dari 30 pasien dengan rata-rata 14,80 menit. Faktor-faktor yang berhubungan dengan waktu layanan rekam medis antara lain perakitan berkas rekam medis, pengisian buku register, pemilahan berkas rekam medis sesuai poliklinik, pengisian buku ekspedisi, ketidakcukupan rak penyimpanan, keberadaan rekam medis di ruang rawatan, terdapatnya rekam medis pada bagian SMF, adanya rekam medis pada poliklinik, pengambilan berkas dari bagian penyimpanan untuk peminjaman apabila diperlukan untuk kepentingan pasien dan keperluan lainnya.

Menurut wawancara dengan teanga rekam medis pada bagian penerimaan rawat jalan, keterlambatan penyediaan rekam medis disebabkan oleh jumlah petugas masih kurang. Jumlah tenaga rekam medis yang ada sebanyak 8 orang dengan kualifikasi pendidikan rekam medis sebanyak 3 orang, perawat 3 dan komputer 2 orang. Terdapatnya fasilitas yang kurang memadai antara lain jumlah komputer 2 buah, tidak tersedianya Kartu Indeks Utama Pasien (KIUP) dan buku registrasi, bank nomor rekam medis tidak tersistematis dan tidak tersusun berurutan.

Selanjutnya masih banyak pasien yang mengeluh pada layanan yang dilakukan seperti kurangnya pengetahuan tentang layanan rekam medis begitu juga dengan pelayanan kesehatan dan efektifitas waktu sehingga pasien menunggu lama sewaktu pendaftaran. Penelitian sebelumnya yang berjudul Tinjauan Lama Waktu Pendistribusian Rekam Medis Pada Pasien Rawat Jalan Di RSU Imelda Pekerja Indonesia Medan menyatakan hasil penelitian menunjukkan bahwa 33 berkas rekam medis $(34,25 \%)$ telah memenuhi standar $\leq$ 10 menit, dan 48 berkas rekam medis $(65,75 \%)$ belum memenuhi standar pelayanan minimal (> 10 menit), dengan rata-rata lama waktu pendistribusian 12,30 menit (Valentina, 2017).

Penelitian oleh Febriyanti dan Kurniadi (2013) tentang deskripsi faktor yang memengaruhi waktu tunggu pada pendaftaran rawat jalan pada RSUD Tugurejo Semarang, sesuai hasil perhitungan diperoleh rata-rata waktu tunggu 6 menit 33 detik untuk pasien baru dan 7 menit 2 detik untuk pasien lama. Keseluruhan 18 petugas terdapat 33,3\% lulusan 
diploma rekam medis. Sarana dan prasarana yaitu tidak terdapat pengeras suara. Sumber daya material yaitu tidak terdapat KIUP dan buku registrasi.Petugas tidak melaksanakan prosedur dimana untuk menyerahkan rekam medis pasien baru di bawa sendiri ke poliklinik. Diketahui bahwa dari 100 pasien sebanyak 36,4\% tidak membawa Kartu Indeks Berobat.

Selanjutnya penelitian oleh Soebarto (2011), menunjukkan bahwa faktor yang sangat memengaruhi waktu tunggu layanan rekam medis pada pendaftaran rawat jalan RSUD Datu Sanggul Rantau yaitu pengambilan berkas di penyimpanan. Pada Sumber Daya Manusia yaitu pendidikan dan Sumber Daya Material adalah bahan atau fasilitas. Didapatkan ratarata waktu tunggu pasien baru yaitu 7 menit 27 detik dan pasien lama yaitu 14 menit 16 detik.

Sesuai dengan uraian latar belakang diatas tentang masalah keterlambatan waktu penyediaan rekam medis rawat jalan dan juga faktor-faktor penyebabnya, maka dilakukan penelitian tentang faktor penyebab keterlambatan waktu penyediaan rekam medis rawat jalan di RSU Madani.

\section{METODE PENELITIAN}

\section{A. Jenis Penelitian}

Jenis penelitian inideskriptif yaitu untuk mengetahui faktor-faktor penyebab keterlambatan waktu penyediaan rekam medis rawat jalan di RSU Madani Tahun 2019. Penelitian ini dilakukan di RSU Madani Medan pada bulan Februari sampai dengan Juni 2019.

B. Populasi

Populasi yaitu pasien yang berkunjung pada bagian pendaftaran rawat jalan dan seluruh tenaga rekam medis di rawat jalan dan penyimpanan.

C. Sampel

Sampel pada penelitian ini dibedakan dua jenis yaitu pasien rawat jalan terdiri dari pasien baru dan lama serta tenaga rekam medis rawat jalan RSU Madani Medan.

D. Jenis Data

1. Data primer adalah pengumpulan data melalui kegiatan penelitian dengan datang langsung ke lokasi penelitian untuk mencari fakta yang bekaitan masalah yang diteliti melalui observasi, yaitu pengamatan langsung terhadap objek untuk mendapatkan gambaran yang tepat mengenai objek penelitian, menyebar kuesioner pada pasien yang berkunjung pada poliklinik rawat jalandan wawancara secara terstruktur dengan seluruh petugas rekam medis pendaftaran rawat jalan.

2. Data sekunder adalah pengumpulan data atau informasi yang menyangkut masalah penelitian dengan mempelajari dan menelaah buku, majalah dan literatur lain yang berkaitan dengan masalah yang ada.

E. Metode Pengumpulan Data

1. Wawancara

Menurut saryono (2012), wawancara dapat dilakukan secara terstruktur maupun tidak terstruktur dan dapat dilakukan dengan langsung atau menggunakan telepon. Pada penelitian ini wawancara yang dilakukan adalah wawancara terstruktur, dimana peneliti menyediakan alat penelitian berisikan pertanyaan tertulis sebagai panduan peneliti dalam mewawancarai langsung tenaga rekam medis.

2. Observasi

Menurut Notoatmodjo (2010), observasi yaitu suatu prosedur terencana, antara lain mencatat jumlah dan taraf aktifitas berhubungann masalah penelitian. Observasi terhadap pelaksanaan rekam medis dan sumber daya material dengan bantuan lembar observasi.

3. Studi Dokumen 
Dokumentasi adalah mencari data atau variabel dan sumber berupa catatan, transkip, buku, surat kabar, majalah, notulen rapat, agenda dan sebagainya. Dalam penelitian ini studi dokumentasi dilakukan dengan menganalisa kebijakankebijakan, misalnya melihat standar operasional prosedur, fasilitas yang dimiliki, buku register, buku peminjaman dan pengambilan rekam medis, dsb.

F. Analisa Data

Analisa data secara deskriptif melalui reduksi data, penyajian dan penarikan kesimpulan, sehingga diperoleh gambaran yang jelas tentang penyebab keterlambatan penyediaan rekam medis rawat jalan di RSU Madani Medan.

\section{HASIL DAN PEMBAHASAN}

\subsection{Hasil}

\section{Pelaksanaan Rekam Medis di RSU Madani}

Penyelenggaraan rekam medis pada rumah sakit meliputi : penerimaan pasien, pencatatan, pengolahan data, penyimpanan dan pengambilan kembali rekam medis dapat dijelaskan sebagai berikut :

\section{Penerimaan pasien}

Penerimaan pasien pada bagian Rawat Jalan RSU Madani dapat diklasifikasikan sesuai dengan jenis kedatangannya yaitu pasien baru dan lama.

a. Pasien Baru adalah pasien pertama kali datang ke rumah sakit untuk keperluan berobat.

Pasien baru mendaftar ke bagian Penerimaan Pasien Rawat Jalan RSU Madani dan diwawancarai oleh petugas pendaftaran untuk identifikasi meliputi: nama pasien, alamat, umur, agama, pekerjaan dan juga menanyakan poliklinik tujuan pasien. Jika pasien belum mengetahui poliklinik tujuannya, petugas akan mengarahkan dengan menganalisa keluhannya.Petugas juga mencatat identitas pasien pada buku register, membuat KIB (Kartu Indeks Berobat), KIUP dan rekam medis baru. Rekam medis baru diserahkan ke poliklinik dan pasien menunggu untuk menerima layanan kesehatan. Selanjutnya petugas mengarahkan pasien menuju kasir untuk memenuhi administrasi. Selanjutnya pasien menyelesaikan administrasi pada kasir dan diperbolehkan untuk pulang.

b. Pasien Lama yaitu pasien yang datang sebelumnya untuk keperluan berobat.

Pasien lama datang pada bagian Penerimaan Pasien Rawat Jalan dengan menunjukkan KIB pada petugas pendaftaran. Jika pasien tidak dapat menunjukkan kartu berobat, petugas mencari data pasien melalui komputer kemudian membuatkan kartu berobat baru sesuai nomor yang sama. Petugas melakukan penulisan pada buku register dan mencari rekam medis pada bagian penyimpanan, setelah ditemukan petugas menyerahkan rekam medis pasien untuk mengantri sesuai poliklinik yang dituju. Selanjutnya pasien diarahkan ke kasir berhubungan administrasi dan diperbolehkan untuk pulang.

\section{Pencatatan Data Pasien}

Pencatatan adalah dokumentasi seluruh informasi medis pasien pada rekam medis sebagai bahan informasi. Rekam medis rawat jalan RSU Madani tidak meiliki buku register khusus dalam pengisian identitas pasien rawat jalan. Pencatatan data sosial atau demografi pasien pada buku tulis biasa, yaitunama, alamat, umur, agama, pekerjaan dan lain-lain. Akan tetapi pada pengisiannama dan alamat pasien kurang lengkap sesuai dengan identitas.

\section{Penyimpanan Rekam Medis}


Sistem penyimpanan di RSU Madani berdasarkan lokasi, yaitu sentralisasi dimana berkas rekam medis baik rawat jalan, rawat inap dan gawat darurat disimpan dalam satu file dan satu rak penyimpanan serta pada ruangan yang sama. Sistem penjajaran berkas rekam medis menggunakan Terminal Digit Flling System, yaitu menjajarkan rekam medis sesuai urutan nomor rekam medis pada kelompok dua angka terakhir.Selanjunya, sistem penomoran yang diterapkan mengadopsiunit numbering system, yaitu pasien hanya diberi satu nomor untuk selamanya berobat di RSU Madani.

\section{Pengambilan Kembali Rekam Medis}

Unit rawat jalan RSU Madani telah memiliki buku peminjaman rekam medis rawat jalan akan tetapi Standar Operasional Prosedur peminjaman rekam medis belum ada. Setelah poliklinik tutup, rekam medis dikembalikan ke unit rawat jalan. Petugas rekam medis rawat jalan langsung memasukan data pasien pada komputer. Data yang diinput ke dalam komputer adalah nomor rekam medis, nama, pasien baru dan lama. Setelah selesai input data, rekam medis disimpan petugas ke ruang penyimpanan.

\section{Waktu Tunggu Pelayanan Rekam Medis pada Pendaftaran Rawat Jalan RSU Madani}

Waktu tunggu layanan adalah waktu pasien menunggu dimulai saat kedatangan pasien pada bagian penerimaan pasien sampai dengan rekam medis didistribusikan ke poli tujuan. Waktu Tunggu Pelayanan meliputi waktu tunggu dari beberapa tahapan dan berbeda untuk pasien baru dan lama. Untuk pasien baru tahapannya yaitu waktu tunggu pada bagian penerimaan pasien, mengisi data pasien pada buku register, membuat KIB, identitifikasi pasien baru dan pendistribusian rekam medis pada poliklinik. Sedangkan untuk pasien lama yaitu waktu tunggu pada bagian penerimaan pasien, identifikasi, mengisi data pasien pada buku register, menemukan rekam medis pasien pada ruang penyimpanan dan pendistribusian rekam medis pada poliklinik.

Berdasarkan perhitungan waktu tunggu pasien pada bagian pendaftaran rawat jalan, diketahui bahwa waktu rata-rata pada pasien baru secara keseluruhan adalah 15 menit 45 detik sedangkan waktu rata-rata pasien lama secara keseluruhan adalah 14 menit 16 detik. Rincian datapada tabel 1 berikut ini.

Tabel 1. Hasil Perhitungan Terhadap Waktu Tunggu Rata-Rata Pada Layanan Dalam Tiap Tahapan Untuk Pasien Baru dan Pasien Lama Pada Bagian Rekam Medis Pendaftaran Rawat Jalan RSU Madani Tahun 2019

\begin{tabular}{ccc}
\hline Tahapan & Pasien Baru & Pasien Lama \\
\hline $\begin{array}{c}\text { Waktu tunggu pada Bagian } \\
\text { penerimaan pasien }\end{array}$ & 6 menit & 5 menit \\
Penyerahan KIB & 53 detik & 2 detik \\
\hline \multirow{2}{*}{ Menulis ke dalam buku register } & - & 3 detik \\
\hline Membuat KIB dan mengisi & 5 menit & 1 menit \\
identitas pasien baru & 5 menit & 6 detik \\
\hline Waktu tunggu penemuan & 38 detik & - \\
rekam medis pasien lama & - & 6 menit \\
\hline Total waktu & 15 menit 45 detik & 14 menit 16 detik \\
\hline
\end{tabular}

\section{Karakteristik Responden}

Berdasarkan hasil penelitian menunjukkan bahwa sebagian besar responden berumur $>22$ tahun sebanyak 5 orang $(71,4 \%)$, sebagian kecil berumur $<22$ tahun sebanyak 2 orang $(28,5 \%)$. Berdasarkan jenis kelamin, sebagian besar responden perempuan sebanyak 6 orang $(85,7 \%)$, sebagian kecil laki-laki sebanyak 1 orang $(14,2 \%)$. Berdasarkan status perkawinan, 
sebagian besar responden belum kawin sebanyak 6 orang $(85,7 \%)$, sebagian kecil responden kawin sebanyak 1 orang $(14,2 \%)$.

Hasil penelitian ini sebagian besar responden bekerja $<5$ tahun sebanyak 6 orang $(85,7 \%)$, sedangkan yang bekerja $>5$ tahun sebanyak 1 orang $(14,2 \%)$. Berdasarkan pendidikan, seluruh responden berpendidikan SLTA/sederajat sebanyak 7 orang $(100,0 \%)$. Berdasarkan pelatihan rekam medis, sebagian besar responden tidak mengikuti pelatihan rekam medis sebanyak 5 orang $(71,4 \%)$, sebagian kecil responden pernah mengikuti pelatihan rekam medis sebanyak 2 orang $(28,5 \%)$. Berdasarkan hasil penelitian, karakteristik responden dapat dilihat pada Tabel 2 berikut ini.

Tabel 2. Distribusi Frekuensi Responden Berdasarkan Karakteristik di Rumah Sakit Umum Madani Tahun 2019

\begin{tabular}{|c|c|c|c|}
\hline No & Karakteristik & Jumlah (n) & Persentase $(\%)$ \\
\hline \multirow[t]{3}{*}{1} & Umur & & \\
\hline & $<22$ tahun & 2 & 28,5 \\
\hline & $>22$ tahun & 5 & 71,4 \\
\hline \multirow[t]{3}{*}{2} & Jenis Kelamin & & \\
\hline & Laki-laki & 1 & 14,2 \\
\hline & Perempuan & 6 & 85,7 \\
\hline \multirow[t]{3}{*}{3} & Status Perkawinan & & \\
\hline & Belum Kawin & 6 & 85,7 \\
\hline & Kawin & 1 & 14,2 \\
\hline \multirow[t]{2}{*}{4} & Pendidikan & & \\
\hline & SLTA/Sederajat & 7 & 100,0 \\
\hline \multirow[t]{3}{*}{5} & Masa Kerja & & \\
\hline & $<5$ tahun & 6 & 85,7 \\
\hline & $>5$ tahun & 1 & 14,2 \\
\hline \multirow[t]{4}{*}{6} & Pelatihan & & \\
\hline & Pernah & 2 & 28,5 \\
\hline & Tidak pernah & 5 & 71,4 \\
\hline & Total & 7 & 100,0 \\
\hline
\end{tabular}

\section{Sumber Daya Material}

Berdasarkan hasil penelitian, sebagian bahan telah tersedia di bagian rekam medis rawat jalan dan penyimpanan, yaitu karcis harian, buku tulis, KIUP, buku peminjaman dan mesin tracer baru api belum dapat digunakan. Tidak terdapat petunjuk rak penyimpanan untuk mempercepat petugas dalam menyimpan dan mengambil kembali rekam medis apabila pasien datang berobat kembali. Tidak terdapatnya kartu permintaan (formulir) bagi peminjam rekam medis rawat jalan dan kode warna pada sampul pelindung BRM. Selanjutnya, tidak ada ditemukan tanda petunjuk untuk BRM yang keluar dari rak penyimpanan dan hanya menggunakan kertas biasa yang ditempel pada sampul rekam medis. Kebutuhan alat diatas secara umum hampir terpenuhi dimana telepon, komputer, pendingin ruangan, rak dan ruangan penyimpananan dan pendaftaran ada dengan jumlah terbatas. Tidak tertutup kemungkinan tenaga rekam mediis untuk mengusulkan alat lainnya terkait dengan kelancaran pelaksanaan rekam medis. Ruang kerja terdapat meja kerja dan rak arsip berbentuk rak terbuka biasa. Fasilitas yang dimiliki unit pendaftaran rekam medis rawat jalan RSU Madani adalah bagian pendaftaran tidak terlau jauh dengan penyimpanan rekam medis aktif. Selanjutnya, ruang pengelolaan data dekat dengan ruang penerimaan pasien. Ruang penyimpanan rekam medis, kondisi ruangan adalah lantai bebas dari banjir, 
dinding permanen, penerangan cukup dan ventilasi kurang baik untuk ruang penyimpanan. Masalah yang didapatkan adalah dinding tidak bersih, jarak yang seharusnya $90 \mathrm{~cm}$ antara rak penyimpanan belum dapat terpenuhi disebabkan luas ruang penyimpanan terbatas, yaitu berjarak $52 \mathrm{~cm}$. Ruang tidak cukup aman dan pemeliharaan kebersihan kurang baik. Keterangan dapat dilihat pada tabel 3 berikut ini.

Tabel 3. Hasil Observasi Sumber Daya Material pada Instalasi Rekam Medis Rawat Jalan RSU Madani Tahun 2019

\begin{tabular}{|c|c|}
\hline Sumber Daya Material & Status \\
\hline \multicolumn{2}{|l|}{ Bahan } \\
\hline Karcis di loket penerimaan pasien & Ada \\
\hline Buku register & Tidak Ada \\
\hline Rekam medis diberi map atau sampul & Ada \\
\hline Kartu Indeks Utama Pasien (KIUP) & TidaAda \\
\hline Tanda petunjuk penyimpan rekam medis & Tidak Ada \\
\hline Kartu permintaan (formulir) peminjam rekam medis & Tidak Ada \\
\hline $\begin{array}{l}\text { Tersedia kode warna map atau sampul untuk mencegah } \\
\text { kekeliruan simpan dan memudahkan mencari map yang salah }\end{array}$ & Tidak Ada \\
\hline $\begin{array}{l}\text { Terdapat petunjuk keluar rekam medis yang tidak berada } \\
\text { dibagian penyimpanan }\end{array}$ & Tidak Ada \\
\hline \multicolumn{2}{|l|}{ Peralatan } \\
\hline Alat tulis kantor & Ada \\
\hline Komputer untuk input data & Ada \\
\hline Buku pedoman pelaksanaan rekam medis & Ada \\
\hline Prosedur tetap (Protap) & Ada \\
\hline Ruang kerja lengkap dengan meja & Ada \\
\hline Rak penyimpanan BRM berbentuk rak terbuka & Ada \\
\hline Telepon & Ada \\
\hline \multicolumn{2}{|l|}{ Fasilitas } \\
\hline $\begin{array}{l}\text { Ruang pendaftaran berdekatan pada penyimpanan rekam } \\
\text { medis aktif }\end{array}$ & Ya \\
\hline Ruang pengelola data tidak jauh dari ruang penerimaan pasien & Ya \\
\hline $\begin{array}{l}\text { Bagian penyimpanan rekam medis } \\
\text { a. Lantai kedap air dan bebas banjir } \\
\text { b. Dinding bersih dan permanen } \\
\text { c. Ventilasi cukup } \\
\text { Jarak antara dua rak minimal } 90 \mathrm{~cm}\end{array}$ & $\begin{array}{l}\text { Ya } \\
\text { Tidak } \\
\text { Tidak } \\
\text { Tidak }\end{array}$ \\
\hline $\begin{array}{l}\text { Bagian penyimpanan rekam medis aktif dapat menampug } \\
\text { BRM }\end{array}$ & Tidak \\
\hline $\begin{array}{l}\text { Bagian penyimpanan rekam medis inaktif berbeda dengan } \\
\text { ruang kerja rekam medis }\end{array}$ & Tidak \\
\hline $\begin{array}{l}\text { Ruang aman dalam melindungi dari kehilangan, kerusakan dan } \\
\text { mencegah penggunaan orang yang tidak mempunyai } \\
\text { kepentingan }\end{array}$ & Tidak \\
\hline $\begin{array}{l}\text { Ruang rekam medis cukup luas untuk petugas rekam medis } \\
\text { untuk menjalankan tugasnya }\end{array}$ & Tidak \\
\hline Ruang rekam medis dekat pada instalasi penunjang & $\mathrm{Ya}$ \\
\hline Penerangan tempat penyimpanan baik & Ya \\
\hline Suhu ruangan tempat bekerja baik & $\mathrm{Ya}$ \\
\hline Pemeliharaan kebersihan baik & Tidak \\
\hline
\end{tabular}




\subsection{Pembahasan}

\section{PelaksanaanRekam Medis}

Penerimaan pasien

Untuk pasien lama tidak membawa KIB dan tidak ditemukan nomornya pada penyimpanan, petugas mencetak kartu dan berkas baru serta pasien tersebut dianggap sebagai pasien baru. Sebaiknya hal ini bisa dihindari karena merugikan pihak pasien dan pihak rumah sakit. Kerugian bagi pihak pasien adalah dokter yang memeriksa tidak mengetahui riwayat penyakit pasien sehingga harus dilakukan pemeriksaan ulang. Sedangkan kerugian rumah sakit, pasien dengan satu nama bisa memiliki lebih dari satu nomor dan menyebabkan jumlah berkas yang disimpan bertambah. Kondisi diatas dapat dihindari jika menggunakan Kartu Indeks Utama Pasien.

KIUP adalah satu teknik untuk mendukung terselesainya layanan pada pasien, karena jika pasien tidak membawa kartu berobat maka KIUP membantu untuk menemukan data pasien yang dibutuhkan. KIUP merupakan kunci utama bagi setiap pasien, sehingga mutlak harus dibuat, baik itu pasien berobat jalan maupun pasien untuk dirawat. KIUP adalah suatu kartu tanda pengenal setiap pasien baru yang disimpan selamanya pada instansi yang bersangkutan. KIUP dibuat berdasarkan atas ringkasan riwayat klinik yang diperoleh dari tempat penerimaan pasien.Karena KIUP merupakan sumber data yang selamanya harus disimpan, maka harus dibuat selengkap dan sejelas mungkin (Depkes RI, 2006).

\section{Pencatatan}

Pencatatan data identitas pasien saat penerimaan pasien di TPPRJ, ditemukan bahwa pencatatan nama dan alamat kurang lengkap. Hal yang perlu evaluasi adalah penulisan nama dan alamat pasien. Petugas hendaknya menuliskan nama dan alamat pasien secara benar dan lengkap. Penulisan nama dan alamat sangatlah penting karena berpengaruh pada lamanya waktu pencarian berkas rekam medis. Selanjutnya keberadaan buku register sangat penting dalam pencatatan data pasien yang berobat ke rumah sakit.

Pencatatan adalah pendokumentasian segala informasi medis pasien ke dalam rekam medis yang akan menjadi bahan informasi. Catatan berdasarkan sumber datanya dibedakan menjadi catatan sosial dan catatan medis. Catatan sosial diperoleh saat penerimaan pasien di tempat pendaftaran pasien rawat jalan (TPPRJ), meliputi nama, alamat, umur, agama dan pekerjaan. Sedangkan data medis diperoleh pasien setelah mendapatkan pelayanan dari dokter, perawat atau petugas kesehatan lainnya seperti petugas laboratorium dan radiologi (Depkes RI, 2006).

Prinsip utama yang harus di taati oleh petugas rekam medis dalam pencatatan adalah : nama pasien harus lengkap, minimal terdiri dua suku kata. Dengan demikian, nama pasien yang akan tercantum dalam rekam medis akan menjadi satu di antara kemungkinan ini :

a) Nama pasien sendiri, apabila nama sudah terdiri dari satu kata atau lebih

b) Nama pasien sendiri dilengkapi dengan nama suami, apabila pasien seorang pasien bersuami

c) Nama pasien sendiri dilengkapi dengan nama orang tua (biasanya adalah nama ayah)

d) Bagi pasien yang mempunyai nama keluarga atau marga, maka nama keluarga atau marga didahulukan dan kemudian diikuti nama sendiri.

Dalam sistem penamaan rekam medis pasien diharapkan :

a) Nama ditulis dengan huruf cetak dan mengikuti ejaan yang disempurnakan

b) Sebagai pelengkap bagi pasien perempuan di akhir nama lengkap ditambah Ny. Atau Nn. Sesuai dengan statusnya

c) Pencantuman titel selalu diletakkan sesudah nama lengkap pasien 
d) Perkataan Tuan, Saudara, Bapak, tidak dicantumkan dalam penulisan nama pasien (Depkes RI, 2006).

\section{Penyimpanan}

Bentuk penyimpanan berkas rekam medis ada dua, yaitu sentralisasi dan desentralisasi. Sentralisasi adalah penyimpanan rekam medis pasien dalam satu kesatuan baik catatan kunjungan poliklinik maupun catatan selama pasien dirawat inap. Sedangkan desentralisasi yaitu penyimpanan dengan melakukan pemisahan antara rekam medis di poliklinik dengan rekam medis di rawat inap. Berkas rekam medis pasien poliklinik disimpan di satu tempat penyimpanan, sedangkan berkas rekam medis pasien rawat inap disimpan di bagian rekam medis. Secara teori sentralisasi lebih baik daripada desentralisasi, tetapi pelaksanaanya sangat tergantung pada situasi dan kondisi masing-masing rumah sakit. Penyimpanan berkas rekam medis dapat menggunakan sistem nomor (numerical). Sistem penomoran yang sering dipakai adalah sistem nomor langsung (straight numerical), sistem angka akhir (terminal digit), dan sistem angka tengah (middle digit) (Depkes RI, 2006).

Cara penyimpanan yang digunakan RSU Madani adalah sentralisasi memiliki keuntungan yaitu jumlah petugas dan biaya yang dibutuhkan sedikit, berkas disimpan dalam satu ruangan sehingga akan meminimalisir duplikasi penomoran rekam medis pasien. Selanjutnya, kekurangannya yaitu kurang efisiennya waktu dan pelayanan sedikit lambat karena berkas rekam medis rawat jalan dan rawat inap bergabung dalam satu rak penyimpanan sehingga menyulitkan petugas untuk mencarinya akibat ketebalan berkas serta rak penyimpanan akan cepat penuh.

\section{Pengambilan Kembali}

Peminjaman dan pengembalian kembali berkas rekam medis dijelaskan sebagai berikut:

a) Permintaan rutin dari poliklinik atau dokter yang melakukan riset, harus diajukan kebagian rekam medis setiap hari pada jam yang telah ditentukan.

b) Poliklinik yang meminta berkas rekam medis harus mengisi buku peminjaman. Petugas harus menulis dengan benar dan jelas nama pasien dan nomor kartu rekam medisnya.

c) Permintaan atau peminjaman rekam medis yang tidak rutin, seperti untuk pertolongan gawat darurat harus dipenuhi sesegera mungkin.

d) Permintaan lewat teelpon juga dilayani dan petugas bagian rekam medis harus mengisi buku peminjaman. Petugas dari bagian lain yang meminta harus datang sendiri untuk mengambil berkas rekam medis dan harus mengisi buku peminjaman (Depkes RI, 2006).

Semua rekam medis dari poliklinik rawat jalan dikembalikan dengan tepat waktu. Data pasien yeng terdapat pada rekam medis, langsung dimasukkan ke dalam komputer terdiri dari : nomor rekam medis, nama, pasien baru dan pasien lama, dll setelah selesai semua rekam medis langsung difilling.

\section{Waktu Tunggu Pelayanan}

Pelayanan rekam medis yang baik dan bermutu tercermin dari pelayanan yang ramah, cepat dan nyaman. Pelayanan rekam medis rawat jalan dimulai dari tempat pendaftaran pasien sampai memperoleh berkas rekam medis yang akan digunakan untuk mendapatkan pelayanan kesehatan. Berdasarkan standar penyediaan berkas rekam medis rawat jalan adalah $\leq 10$ menit, dan rekam medis rawat inap $\leq 15$ menit (Depkes RI, 2008). Rata-rata waktu tunggu yang dibutuhkan untuk pasien baru rawat jalan di RSU Madani adalah 15 menit 45 detik dan pasien lama adalah 14 menit 16 detik. Rata-rata waktu tunggu pelayanan rekam medis pasien baru di pendaftaran rawat jalan sangat lama dan jauh dari standar waktu 
yang ditetapkan. Sedangkan rata-rata waktu tunggu pelayanan rekam medis pasien lama di pendaftaran rawat jalan sedikit lama jika dibandingkan dengan standar.

\section{Sumber Daya Manusia}

Sumber Daya Manusia (SDM) merupakan aset rumah sakit yang sangat penting dan merupakan sumber daya yang berperan besar dalam pelayanan rumah sakit. Penanganan SDM penting karena mutu pelayanan rumah sakit sangat tergantung dari perilaku SDM. Kemajuan ilmu dan teknologi memerlukan tenaga yang profesional dan spesialistis (Pohan, 2007). Mutu pelayanan rumah sakit yang dimaksud adalah semua jenis pelayanan termasuk pelayanan pendaftaran pasien rawat jalan.

Berdasarkan hasil penelitian diketahui bahwa jumlah petugas rekam medis di unit rawat jalan dan penyimpanan RSU Madani sebanyak 7 orang. Tingkat pendidikan, pengalaman dan pelatihan memegang peran penting dalam melakukan pekerjaaannya. Untuk tercapainya kesuksesan dalam bekerja dituntut pendidikan yang sesuai dengan jabatan yang dipegang individu. Tingkat pendidikan formal petugas adalah SLTA/sederajat dan tidak ada berpendidikan rekam medis. Untuk pendidikan non formal atau frekuensi petugas mengikuti pendidikan, pelatihan, seminar dan sebagainya mempunyai intensitas yang sedikit. Dengan demikian kebutuhan akan kualitas tenaga profesional di unit rawat jalan dan penyimpanan RSU Madani belum dapat terpenuhi. Dimana pelatihan SDM sangat diperlukan agar terselenggara pelayanan yang bermutu guna menjamin pelayanan sesuai dengan standar dan kebutuhan (Widjono, 2000).

\section{Sumber Daya Material}

Penyelenggaraan kegiatan rekam medis perlu didukung keberadaan sumber daya material yang meliputi bahan, peralatan dan fasilitas. Bahan adalah formulir dan kartu atau sejenisnya yang telah dicetak sesuai ketentuan yang menunjang pelaksanaan rekam medis. Fasilitas dan peralatan adalah segala sesuatu yang menunjang kemudahan pelaksanaan tugas dan pengelolaan rekam medis. Alat penyimpanan yang tepat, penerangan dan pengaturan suhu yang baik, pemeliharaan ruangan, serta perhatian terhadap faktor keselamatan dan kesehatan kerja sangat membantu pemeliharaan, mendorong kegairahan kerja dan meningkatkan produktifitas petugas. Alat penyimpanan berkas yang umum digunakan adala rak terbuka (open shelves file unit), lemari lima laci (five drawers file cabinet) atau rak buka tutup (roll o'pack). Jarak antara dua buah rak untuk lalu lalang dianjurkan selebar $90 \mathrm{~cm}$, jika menggunakan lemari lima laci maka sebaiknya dijajarkan satu baris dan ruang kosong didepannya harus $90 \mathrm{~cm}$, jika diletakan berhadapan harus disediakan ruang lowong $150 \mathrm{~cm}$ untuk memungkinkan membuka laci tersebut. Lemari lima laci memang tampak lebih rapi dan berkas rekam medisnya terlindung dari debu dan kotoran dari luar. Namun penggunaan rak terbuka lebih praktis dalam mempermudah pengambilan berkas rekam medis (Depkes RI, 2006).

Pada deretan map rekam medis yang disimpan harus diberi tanda petunjuk untuk mempercepat pekerjaan penyimpanan dan menemukan rekam medis. Berkas rekam medis hendaknya diberi sampul pelindung untuk memelihara keutuhan susunan lembaran rekam medis dan mencegah terlepas atau rusaknya lembaran, akibat seringnya diambil atau dibuka. Sampul atau map pelindung dilengkapi dengan penjepit (fastener) untuk menggabungkan lembaran pada sampul (Depkes RI, 2006).

Bahan penunjang pelaksanaan rekam medis telah tersedia di bagian rekam medis rawat jalan yaitu karcis harian, buku tulis untuk register, buku peminjaman, tracer manual, dll. Tidak terdapat tanda petunjuk guna mempercepat pekerjaan menyimpan dan menemukan rekam medis, tidak ada tersedia kartu permintaan (berbentuk formulir) bagi peminjam rekam medis rawat jalan dan kode warna map serta tanda petunjuk untuk berkas rekam medis yang 
keluar(dipinjam). Tanda petunjuk untuk berkas keluar digunakan untuk menggantikan berkas yang keluar dari rak. Petunjuk tetap berada di tempat tersebut sampai berkas dikembalikan. Dengan adanya out guide petugas dapat mengetahui secara cepat bila berkas yang dibutuhkan tidak ada. Dengan demikian petugas tidak akan melakukan pencarian yang lama pada waktu berkas tersebut dibutuhkan khususnya untuk pasien lama. Keberadaan map maupun out guide akan berpengaruh pada waktu tunggu pelayanan pasien karena kedua bahan tersebut dapat mempercepat proses penemuan dan penyimpanan berkas.

Peralatan yang dibutuhkan sebagian besar telah tersedia meliputi ATK, komputer untuk entry data, buku pedoman pelaksanaan rekam medis, prosedur tetap, rak berkas dan telepon. Ketersediaan peralatan tersebut seperti komputer harus ditunjang dengan pemanfaatan yang optimal. Pemanfaatan optimal akan memperlancar pelaksanaan kegiatan sehingga berakibat pada waktu tunggu pasien menjadi lebih singkat.

Fasilitas yang dimiliki unit rekam medis rawat jalan dan penyimpanan di RSU Madani, yaitu ruang pendaftaran pasien berdekatan dengan ruang penyimpanan rekam medis aktif. Selanjutnya, ruang pengelolaan data berdekatan dengan ruang penerimaan pasien.Ruang penyimpanan rekam medis, meliputi keadaan lantai yang bebas banjir, dinding permanen, penerangan cukup dan suhu telah terpenuhi. Pada ruang penyimpanan, memiliki rak terbuka dimana jarak antara rak satu dengan yang lainnya tidak memenuhi standar yaitu $52 \mathrm{~cm}$. Petugas harus bergantian untuk dapat melewati satu jalur pada ruang penyimpanan. Hal ini disebabkan oleh ruang penyimpanan kurang luas yaitu terdapat di lantai satu dan lantai dua rumah sakit. Akibatnya, tidak dapat menampung rak terbuka penyimpanan yang seharusnya disusun dengan jarak antara rak $90 \mathrm{~cm}$ (Depkes, 2006). Hal ini secara tidak langsung dapat menghambat pencarian berkas dan akan berakibat pada waktu tunggu pasien.

Tabel 4. Faktor-Faktor Yang Memengaruhi Waktu Tunggu Pasien Terhadap Penyediaan Rekam Medis Rawat Jalan di RSU Madani Tahun 2019

\begin{tabular}{ll}
\hline No & Faktor Yang Memengaruhi Waktu Tunggu \\
\hline 1 & $\begin{array}{l}\text { SDM atau petugas rekam medis yang terbatas jumlahnya dan pendidikan tidak } \\
\text { rekam medis. }\end{array}$ \\
\hline 2 & $\begin{array}{l}\text { Peralatan penunjang masih kurang, meliputi : telepon, kartu permintaan } \\
\text { formulir, Kartu peminjaman, komputer dan lain-lain. }\end{array}$ \\
\hline 3 & $\begin{array}{l}\text { Sistem penyimpanan yang kurang baik, sehingga petugas rekam medis rawat } \\
\text { jalan sulit menemukan berkas rekam medis }\end{array}$ \\
\hline 4 & Disiplin petugas yang kurang baik, sering petugas datangnya tidak tepat waktu. \\
\hline 5 & $\begin{array}{l}\text { Petugas rekam medis rawat jalan dan penyimpanan bekerja menggunaka secara } \\
\text { manual atau tidak terkomputerisasi. }\end{array}$ \\
\hline
\end{tabular}

\section{KESIMPULAN}

Berdasarkan hasil penelitian dan pembahasan yang telah diuraikan di atas, dapat disimpulkan sebagai berikut :

1. Penyelenggaraan rekam medis di RSU Madani Medan, yaitu dari penerimaan pasien, pencatatan, pengolahan data, penyimpanan dan pengambilan kembali berkas rekam medis.

2. Rata-rata waktu tunggu pelayanan rekam medis rawat jalan untuk pasien baru 15 menit 45 detik dan pasien lama 14 menit 16 detik. Hal ini tidak sesuai denganstandar pelayanan minimal dalam rekam medis, yaitu $\leq 10$ menit.

3. Sumber Daya Manusia (SDM) meliputi jumlah petugas, pendidikan, umur dan masa kerja. Faktor penyebab keterlambatan penyediaan rekam medis rawat jalan di RSU Madani yaitu pendidikan dan pelatihan. 
4. Sumber Daya Material rekam medis meliputi bahan, peralatan dan fasilitas.Faktor penyebab keterlambatanpenyediaan rekam medis rawat jalan di RSU Madani yaitu bahan dan fasilitas.

\section{REFERENCES}

Budi, Savitri Citra.M.PH. 2011. Manajemen Unit Kerja Rekam Medis. Jogjakarta: Quantum Sinergis Media.

Bustami MS, MQIH. 2011. Penjaminan Mutu Pelayanan Kesehatan dan Askeptabilitasnya. Jakarta : Penerbit Erlangga.

Departemen Kesehatan RI. 2006. Pedoman Penyelenggaraan dan Prosedur Rekam Medis di Rumah Sakit. Jakarta: Direktorat Jendral Bina Pelayanan Medik. Revisi 2.

Departemen Kesehatan Republik Indonesia, 2009. Undang-undang Republik Indonesia. Nomor 44 tentang Rumah Sakit. Depkes RI. Jakarta.

Dhamanti, Inge. (2003). Analisis Faktor Yang Mempengaruhi Waktu Tunggu Pelayanan Rekam Medis Rawat Jalan (Studi di Rekam Medis Rawat Jalan RSU Haji Surabaya). Penelitian Ilimiah .Universitas Airlangga Surabaya.

Hatta R, Gemala. 2011. Pendoman Manajemen Informasi Kesehatan di Sarana Pelayanan Kesehatan. Jakarta: Penerbit Universitas Indonesia.

Huffman, Edna K. 1994. Health Information Management 10 Edition. Illionis : physicions Record Company.

Keputusan Menteri Kesehatan RI. 2008. No.129 SK II .Tentang Standar Pelayanan Minimal Rumah Sakit. Jakarta: Menteri Kesehatan.

Keputusan Mentri Kesehatan RI. 2008. No.269 PER III. Tentang Rekam Medis. Jakarta: Menteri Kesehatan.

Konsil Kedokteran Indonesia. (2006). Manual rekam medis. Jakarta: Konsil Kedokteran Indonesia.

Notoadmodjo, S. 2005. Metogologi Penelitian Kesehatan. Rineka Cipta. Jakarta.

Notoadmodjo, S. 2010. Kesehatan Masyarakat Ilmu \& Seni. Rineka Cipta. Jakarta.

Peraturan Menteri Kesehatan Republik Indonesia Nomor: 269/MENKES/PER/III/2008 Tentang Rekam Medis.

Rustiyanto, Ery. 2009. Etika Profesi Perekam Medis \& Informasi Kesehatan. Yogyakarta. Graha Ilmu.

Rustianto, Ery., Rahayu, Warih Ambar. 2011. Manajemen Filing Dokumen Rekam Medis Dan Informasi Kesehatan. Politeknik Kesehatan Permata Indonesia. Jogjakarta. 
Saryono. 2010. Metodologi Penelitian Kesehatan. Mitra Cendika. Jogjakarta.

Sekretariat Negara. 2009 Undang-Undang RI No.44. Tentang Rumah Sakit. Jakarta: Pemerintah.

Wijono, Djoko. 1999. Manajemen Mutu Pelayanan Kesehatan. Airlangga UniversityPress

Valentina. (2017). Tinjauan Lama Waktu Pendistribusian Rekam Medis Pada Pasien Rawat Jalan Di Rsu Imelda Pekerja Indonesia Medan Tahun 2016. JURNAL ILMIAH PEREKAM DAN INFORMASI KESEHATAN; Vol 2 No 1 (2017): Jurnal Ilmiah Perekam Dan Informasi Kesehatan, 2(1), 248-254. http://ojs.stikesimelda.ac.id/index.php/jipdik/article/view?path=

\section{BIOGRAPHIES OF AUTHORS}

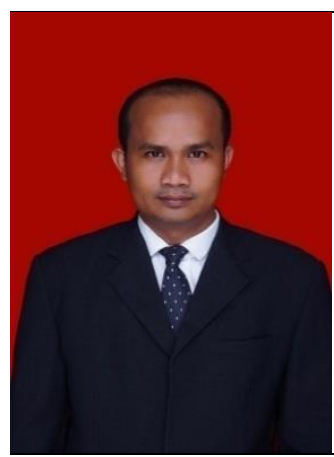

Zulham Andi Ritonga, Gelar D3 dipeoleh dari AKPER Imelda Medan tamat tahun 2003, S1 dari Fakultas Kesehatan Masyarakat Universitas Sumatera Utara minat studi Administrasi Kebijakan Kesehatan tamat pada tahun 2011, dan S2 dari Fakultas Kesehatan Masyarakat Universitas Sumatera Utara minat studi Administrasi Rumah Sakit tamat tahun 2019. Saat ini staf pengajar di D-III Perekam Medis dan Informasi Kesehatan Universitas Imelda Medan. 